\title{
Implementasi Metode Pembelajaran Baca Al-Qur'an Di Taman Pendidikan Al-Qur'an (TPA) Bani Lathif Bandar Lampung
}

\section{Implementation of the Al-Qur'an Reading Learning Method in the Al-Qur'an Education Park Bani Lathif Bandar Lampung}

\author{
Sumiyati $^{1}$ \\ ${ }^{1}$ Universitas Sang Bumi Ruwa Jurai. Jalan Imam Bonjol No. 486, Langkapura, Bandar Lampung \\ 35118, Indonesia. \\ *Corresponding Author. E-mail: Sumiiyati216@gmail.com
}

\begin{abstract}
Abstrak
Penelitian ini bertujuan untuk mengetahui implementasi Metode Pembelajaran Baca al-Qur'an di Taman Pendidikan al-Qur'an (TPA) Bani Lathif Bandar Lampung. Penelitian ini menggunakan pendekatan deskriptif kualitatif. Teknik-teknik pengumpulan datanya digunakan teknik obsevasi, wawancara dan dokumentasi. Setelah data yang diperlukan terkumpul, maka langkah selanjutnya adalah analisa data. Teknik analisis data yang digunakan terdiri dari tiga langkah, yaitu reduksi data, penyajian data dan penarikan kesimpulan serta verifikasi. Hasil penelitian menunjukkan bahwa implementasi metode pembelajaran baca al-Qur'an di TPA Bani Lathif diimplementasikan melalui pelaksanaan komponen-komponen pembelajarannya. Dari aspek tujuan, penguasaan huruf hijaiyyah, tanda baca, tajwid dan dapat mempraktikkan baca al-Qur'an dengan baik dan benar sesuai dengan kaidah makharijul huruf. Mereka diharpkan pula dapat menghayati dan mengaplikasikannya dalam kehidupan sehari-hari. Dari segi materi, lebih sederhana daripada metode lainnya, di mana santri tidak diberikan buku paket, namun materi dituliskan di papan tulis untuk melatih keterampilan menulis dan memperkuat hafalan, meski terkesan kurang efisien. Sistem yang digunakan dalam pembelajarannya antara lain dengan variasi sistem individual/ private, klasikal dan klasikal tulis, baca simak "tadarus". Adapun media yang digunakan masih sederhana yakni dengan mengoptimalkan yang ada, dan menuntut kreativitas guru. Evaluasi dilakukan melalui tiga tahapan: evaluasi harian, evaluasi pergantian pokok bahasan; evaluasi khatam al-Qur'an atau tes kelulusan. Meskipun demikian, dalam pelaksanaan belum terdapat perencanaan tertulis sebagaimana pada pendidikan formal, yang mengharuskan guru untuk membuat RPP sebelum melakukan proses pembelajaran.
\end{abstract}

Kata kunci: Metode Pembelajaran, Rumah Tahfidz, Taman Pendidikan Al-quran

\begin{abstract}
This study aims to describe the implementation of learning methods to read al-Qur'an in the al-Qur'an education park (TPA) of Bani Lathif Bandar Lampung.The data collection techniques used were observation, interview and documentation techniques. After the required data has been collected, the next step is data analysis. The data analysis technique used consists of three steps, namely data reduction, data presentation, drawing conclusions and verification. The results showed that the implementation of the learning method to read al-Qur'an in TPA Bani Lathif can be described through the implementation of the learning components. From the aspect of objectives, mastery of hijaiyyah letters, punctuation, tajwid and being able to practice reading the Koran properly and correctly in accordance with the rules of the letter makharijul. They are also expected to be able to appreciate and apply it in everyday life. In terms of material, it is simpler than other methods, in which students are not given textbooks, but the material is written on the blackboard to practice writing skills and strengthen memorization, although it seems less efficient. The systems used in learning include a variety of individual / private systems, classical and classical writing, read see "tadarus". The media used is still simple, namely by optimizing what is available, and demands teacher creativity. The evaluation is carried out in three stages: daily evaluation, evaluation of subject changes; Khatam al-Qur'an
\end{abstract}


evaluation or graduation test. However, in implementation there is no written planning as in formal education, which requires teachers to make lesson plans before carrying out the learning process.

Keywords: Learning Methods, Tahfidz House, Quran Education Park

\section{PENDAHULUAN}

\section{Secara sederhana implementasi bisa diartikan pelaksanaan atau} penerapan (Irawan \& Herviana, 2018; Puspita et al., 2016). Al-Quran menurut istilah (terminology) kalam Allah yang tiada tandingannya (mukjizat) diturunkan kepada Nabi Muhammad SAW penutup para nabi dan rasul, dengan perantara malaikat Jibril AS (Zaini, 2019). Salah satu cara terpenting untuk mendidik dan membina anak adalah dengan memberinya pendidikan al-Qur'an sejak masa kanak-kanak, karena pada masa ini adalah masa pembentukan watak yang ideal(Iqbal \& Rizal, n.d.). Mendidik anak untuk mengenal al-Qur'an dapat dilakukan baik oleh orang tua anak tersebut maupun pendidik. Adapun tujuan pendidikan al-Qur'an diberikan pada masa kanak-kanak adalah untuk memudahkan anak mengenal, mempelajari dan memahami isi al-Qur'an di masa yang akan datang.

Menurut Abuddin Nata, Surat al'Alaq mengandung pesan tentang perlunya mengembangkan pendidikan dan pengajaran yang memuat komponenkomponen pendidikan yaitu: Komponen guru, dalam ayat ini Allah SWT yang berperan memerintahkan kepada nabi Muhammad; (2) Komponen murid, yang dalam ayat ini adalah nabi Muhammad; (3) Komponen metode, yaitu membaca (Iqra') sehingga muncul metode Iqra'; (4) Komponen sarana pra sarana, yang dalam ayat diwakili oleh kata kalam (pena) dan (5) Komponen kurikulum.

Mengingat demikian pentingnya peran al-Qur'an dalam memberikan dan mengarahkan kehidupan manusia, maka belajar membaca, memahami, dan menghayati al-Qur'an untuk kemudian diamalkan dalam kehidupan sehari-hari merupakan kewajiban bagi umat Islam. Oleh karena itu, orang tua mesti turut memperhatikan dan bertanggungjawab terhadap perkembangan agama anakanak. Karena perkembangan agama pada anak sangat ditentukan oleh pendidikan dan pengalaman yang dilaluinya, terutama pada masa pertumbuhan pertama (masa anak) dari berumur 0-12 tahun (Jafri, 2021; Munirah \& Ladiku, 2019).

Kemampuan anak untuk menyerap pengalaman-pengalaman yang dilaluinya dan hal-hal yang ada disekitar mereka sangat luar biasa. Adapun kewajiban orang tua untuk mendidik anak membaca al-Qur'an tertera dalam Hadits berikut:

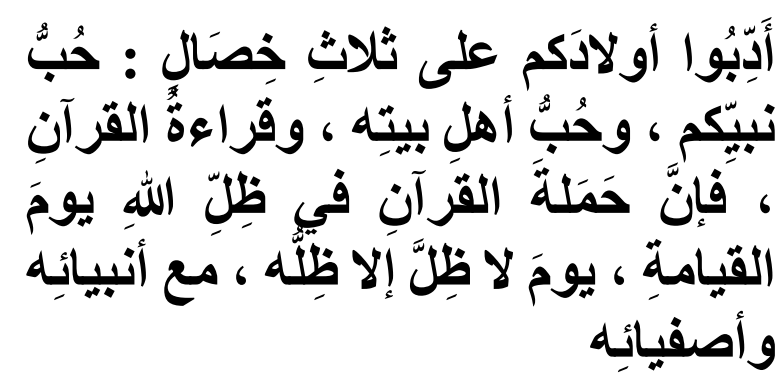

Artinya: "Didiklah anakmu dengan tiga perkara, yaitu mencintai Nabimu, mencintai keluarga Nabi, dan membaca alQur'an, sesungguhnya orang yang berpegang teguh pada al-Qur'an berada pada perlindungan Allah SWT pada hari tidak ada perlindungan kecuali lindunganNya bersama-sama dengan Nabi-nabi dan Sahabat-sahabatnya yang tulus." (H.R. alDaylami 'an 'Iliyyi)

Untuk mengantisipasi hal tersebut, umat Islam semestinya mengoreksi diri dan melakukan langkah-langkah positif untuk mengembangkan pembelajaran alQur'an, sebagai salah satu media untuk belajar dan memperdalam isi kandungan al-Qur'an. Untuk itu, pembelajaran al- 
Qur'an perlu ditingkatkan dengan menggunakan metode dan teknik belajar baca al Qur'an yang praktis, efektif, dan efesien, serta dapat mengantarkan bagaimana siswa atau santri cepat dan tanggap untuk pembelajaran membaca alQur'an pada saat sekarang ini (Latifah et al., 2021).

Dengan demikian mengingat pentingnya pembelajaran al-Quran maka diperlukan adanya metode. Metode adalah seperangkat cara, jalan dan teknik yang dipakai oleh guru (pendidik) dalam proses belajar mengajar agar siswa (murid, peserta didik) mencapai tujuan pembelajaran atau kompetensi tertentu (Asy'ari, 2014). Dengan demikian metode digunakan sebagai alat untuk mencapai tujuan pembelajaran. Dalam proses belajar mengajar (PBM), metode merupakan komponen pembelajaran yang penting. metode menempati posisi kedua terpenting setelah tujuan dari sederetan komponen-komponen pembelajaran: tujuan, metode, materi, media dan evaluasi (Nasution, 2020).

Dalam proses belajar baca alQur'an, metode yang baik akan berpengaruh kuat terhadap keberhasilan santri/ anak didik, sehingga tercipta keberhasilan dalam Pembelajaran baca alQur'an yang sesuai dengan kaidah-kaidah ilmu al-Qur'an. Metode pembelajaran baca al-Qur'an yang praktis, efektif, dan efesien serta cepat memahami pembelajaran alQur'an di mana dapat menghantarkan anak didikannya mampu mengembangkan baca tulis al-Qur'an, saat ini banyak ditemukan. Metode-metode ini menawarkan cara-cara baru yang berbeda dengan cara-cara lama, sebagaimana yang dituntunkan oleh al-Qawaidul Baghdadiyah (Mesnawi \& Najamuddin, 2015).

Dengan ditemukannya sejumlah metode ini, yang kemudian dibarengi dengan gerakan TK al-Qur'an dan Taman Pendidikan al-Qur'an (TKA-TPA), di seluruh tanah air telah terjadi suasana dan gairah baru dalam pembelajaran membaca al-Qur'an. Apabila metode pembelajaran al-Qur'an tersebut dapat diterapkan secara cepat (efektif, praktis, dan efesien), diharapkan target mencetak generasi yang Qur'ani di masa mendatang dapat terwujud.

Taman Pendidikan al-Qur'an Bani Lathif Bandar Lampung adalah salah satu TPA yang cukup dikenal dan diminati terutama di kota Bandar Lampung. Hal itu dapat dibuktikan dengan meningkatnya jumlah santri yang mendaftar di TPA ini. Data dua tahun terakhir menunjukkan bahwa hanya dua kelas santri (tercatat 100 sampai 125 orang) yang dapat ditampung, sedangkan pendaftar melibihi kapasitas sarana kelas yang dimiliki oleh TPA Bani Lathif.

Berdasarkan

penelitian sebelumnya oleh Tsaqifa dkk menunjukan hasil bahwa (1) metode Iqro' diimplementasikan secara klasikal, privat, mengenalkan bunyi huruf hijaiyah, membaca langsung Iqro' "versi" AMM dan sistem CBSA; (2) Sistematika metode Iqro' dalam pembelajaran membaca Al-Qur'an melalui tahapan-tahapan mulai dari jilid 1-6 yang disusun oleh pihak AMM Kotagede Yogyakarta dimulai dari yang sederhana menjadi kompleks; dan (3) Metode Iqro' memiliki kelebihan yaitu sudah diterapkan di seluruh Indonesia dan sebagian Negara ASEAN, fleksibel, buku ajar nya mudah didapatkan dan harganya terjangkau, menggunakan sistem CBSA, dapat khatam Iqro' dengan waktu yang singkat, praktis, sistematis, dan variative (Ulfah et al., 2019).

Sejak awal berdirinya, TPA Bani Lathif sudah menerapkan metodenya sendiri yang telah diwariskan oleh para pendirinya. Meskipun banyak metode yang saat ini berkembang, seperti metode Iqra', Qira'ati, al-Barqi, dan Tilawati, namun TPA ini tetap mempertahankan tradisi yang telah diwariskan oleh pendiri dan penyusun metodenya. Metode yang digunakan ini dapat menjadi metode 
alternatif yang dapat digunakan dan diterapkan dalam proses belajar mengajar baca al-Qur'an, karena mudah diterapkan dan dipahami anak didik. Metode tersebut pada dasarnya merupakan pengembangan dari metode Baghdadi, sehingga mirip dengan metode Iqra' atau metode lainnya. Akan tetapi, metode ini lebih menekankan dan lebih unggul pada aspek kebenaran makharijul huruf, dan kaidah-kaidah tajwid serta tulis Arab (Latifah et al., 2021), sehingga anak didik tidak hanya lancar membaca al-Qur'an, melainkan paham tentang kaidah-kaidah tajwidnya yang benar dan mampu menulis huruf Arab. Meskipun usianya lebih tua dari metode Iqra', metode Qira'ati dan lainnya, dilihat dari tingkat keberhasilannya tidak kalah jika dibanding dengan metode lainnya.

Berdasarkan penelitian sebelumya Kualitas pembelajaran pendidikan agama Islam, belum sesuai dengan harapan. Pembelajaran sering berorientasi pada penguasaan materi dan bersifat normatif Akibatnya siswa dan pendidik terbebani untuk menyelesaikan materi tanpa berfikir ke depan.

Selanjutnya penelitian lain menunjukan hasil dari implementasi pembelajaran bagi santri pertama, santrisantri diajarkan untuk menghafal, membaca, menulis, dan men-tadabbur alQuran. Kedua, faktor yang menjadi pendukung implementasi metode pembelajaran Alquran bagi santri usia tamyiz di Kuttab Al-Fatih Bantarjati Kota Bogor ialah (1). adab, (2). orang tua, dan (3) kompetensi guru. Ketiga, faktor yang menjadi penghambat implementasi metode pembelajaran Alquran bagi santri usia tamyiz di Kuttab Al-Fatih Bantarjati Kota Bogor ialah (1). adab yang tidak baik, dan (2). kurangnya kontrol orangtua di rumah. Keempat, solusi dari faktor penghambat implementasi metode pembelajaran Alquran bagi santri usia tamyiz di Kuttab Al-Fatih Bantarjati Kota Bogor ialah (1). dialog empat mata dengan santri dan (2). komunikasi antara guru dan orangtua.

Berdasarkan uraian di atas, penelitian ini bertujuan utnuk mengetahui implementasi Metode Pembelajaran Baca al-Qur'an di Taman Pendidikan al-Qur'an (TPA) Bani Lathif Bandar Lampung.

\section{METODE}

Penelitian ini menggunakan pendekatan deskriptif kualitatif. Sumber data utamanya adalah Guru, Kepala TPA dan santri TPA Bani Lathif Bandar Lampung. Adapun sumber skundernya berupa dokumen, arsip, buku, dan lain sebagainya. Teknik-teknik pengumpulan datanya digunakan teknik obsevasi, wawancara dan dokumentasi. Setelah data yang diperlukan terkumpul, maka langkah selanjutnya adalah analisa data. Teknik analisis data yang digunakan terdiri dari tiga langkah, yaitu reduksi data, penyajian data dan penarikan kesimpulan serta verifikasi.

\section{HASIL DAN PEMBAHASAN}

Dalam pembelajaran, rencana pembelajaran di TPA Bani Lathif belum tertulis, sebelum mengajar guru di TPA Bani Lathif tidak membuat rencana pembelajaran (RPP), sehingga mengakibatkan guru kurang persiapan sebelumnya serta kurangnya efisien dan efektif dalam menggunakan waktu yang ada. Terkadang waktu habis digunakan untuk klasikal dan private, sedangkan materi tambahan tidak tercukupi. Oleh karena itu, menuntut kreatifitas, pengalaman dan pengetahuan guru dalam mengajar. Di anatara solusi yang diambil untuk mengatasi belum adanya pembuatan rencana pengajaran, yaitu dengan adanya koordinasi dari para guru baik sebelum atau sesudah pembelajaran guna untuk mengetahui sejauhmana materi yang telah disampaikan. Kemudian dapat pula diatasi rapat guru untuk membahas dan mengevaluasi 
permasalahan-permasalahan, baik dalam pembelajaran atau yang bersangkutan dengan guru dan santri, sehingga bisa dipecahkan bersama. Selama ini penerapan Metode Pembelajaran Baca alQur'an di TPA Bani Lathif berjalan sebagaimana yang telah diwariskan oleh para pendiri dan guru-guru sebelumnya yang merupakan keluarga besar. Belum terlihat adanya inovasi atau perbaikan dari apa yang telah berjalan selama bertahun-tahun di TPA Bani Lathif.

Meski tidak dirumuskan secara tegas dan jelas, sebab guru tidak membuat perencanaan, namun tujuan Pembelajaran Baca al-Qur'an di TPA Bani Lathif secara implisit dapat dipahami melalui target yang ingin dicapai dan dipenuhi yaitu mengandung tujuan kognitif, afektif dan psikomotorik. Pengajaran tentang hurufhuruf hijaiyah, tanda baca dan tajwid merupakan tujuan kognitif. Adapun tujuan psikomotoriknya adalah praktek membaca al-Qur'an dengan baik dan benar sesuai kaidah makharijul huruf. Sedangkan tujuan afektif dari pembelajaran membaca al-Qur'an adalah agar santri nantinya mampu menghayati isi kandungan al-Qur'an dan mengamalkannya dalam kehidupan sehari-hari.

Dalam pengajarannya secara umum Metode Pembelajaran Baca al-Qur'an di TPA Bani Lathif ini dibagi menjadi 3 (tiga) tahap, yaitu: Tahap pertama, selama tiga bulan pertama: dimana santri dikenalkan huruf-huruf hijaiyyah dengan makhrajnya yang benar; guru memberikan contohcontoh yang bervariasi berikut cara penulisannya; setiap dua atau tiga hari sekali huruf-huruf yang diajarkan ditambah; setiap menambah huruf terlebih dahulu dituliskan oleh guru dipapan tulis baik huruf dan macammacam bentuknya; guru menerangkan dan membetulkan makhraj huruf tersebut; para santri disuruh untuk membaca bersama-sama dengan dibimbing oleh gurunya; setelah beberapa kali membaca secara bersama-sama maka para santri diperintahkan untuk menulis dibuku tulis mereka masing-masing; setelah itu santri-santri disuruh maju untuk membacanya satu persatu; guru memperhatikan secara seksama makhraj (cara pengucapan) dan cara penulisan huruf harus dibetulkan benar agar hurufhuruf yang nantinya dibaca oleh para santri menjadi benar terutama hurufhuruf yang sangat sulit; huruf sulit dan tanda baca (fathah, kasrah, dhummah, tasydid) tersebut diajarkan lebih awal berdasarkan klasifikasi makhraj-nya.

Adapun pembelajaran tajwid dalam Metode Pembelajaran Baca al-Qur'an di TPA Bani Lathif ini baru dimulai pada pada bulan keempat, kelima dan keenam santri belajar di TPA ini. Langkah-langkahnya dimulai santri diajarkan ilmu tajwid dengan contoh-contohnya; contoh-contoh tersebut dikutip dari ayat-ayat al-Qur'an; materi tajwid yang diajarkan yang sangat perlu untuk para santri meningkat ketahap ketiga, seperti tanda panjang tiga alif, hukum nun mati dan tanwin, hukum mim mati, fawatihussuwar dan tandatanda waqaf.

Aplikasi Baca al-Qur'an (al-Qur'an 30 juz) dimulai di bulan ke tujuh hingga bulan ke 12. Jadi masa belajar santri untuk menyelesaikan pendidikan baca alQur'anya di TPA ini kurang lebih selama satu tahun. Para santri mengaplikasikan ilmunya yang didapat pada tahap kedua tadi dengan membaca al-Qur'an secara tadarus, daan tetap mengajarkan ilmu tajwid lainnya yang pada tahap kedua belum diajarkan. Santri mulai diajarkan pengetahuan agama Islam lain, seperti aqidah, akhlak, ibadah terutama bacaanbacaan shalat dan doa-doa serta menghafal surat-surat pendek (juz amma). Tahap Akhir, Evaluasi Akhir dan Khatam al-Qur'an Para santri dievaluasi penguasaannya aqidah, dan akhlak. Evaluasi praktek ibadah terutama bacaanbacaan shalat dan doa-doa serta menghafal surat-surat pendek (juz 
amma). Khatam al-Qur'an yang dilaksanakan di akhir tahun ajaran, aspek ada dan fashahah dinilai oleh dewan hakim dari luar (selain guru TPA Bani Lathif).

Namun, lamanya setiap tahap di atas juga tergantung pada jumlah santri dalam satu kelas, kalau santri sedikit mungkin dalam waktu dua bulan sudah dapat meningkat ketahap kedua. Bahkan mungkin pada bulan keempat para santri sudah dapat untuk membaca al-Qur'an.

Dengan demikian, dapat dikatan bahwa pelaksanaan Metode Pembelajaran Baca al-Qur'an di TPA Bani Lathif sudah cukup baik. Selain didukung penguasaan dan kreatifitasan guru dalam mengajar. Guru yang mempunyai ketrampilan dan pengetahuan dalam penerapan Metode Pembelajaran Baca al-Qur'an di TPA Bani Lathif, serta mampu mengoptimalkan semua sarana yang ada untuk pembelajaran Baca al-Qur'an.

Dalam penerapan Metode Pembelajaran Baca al-Qur'an di TPA Bani Lathif juga mengandung tiga aspek dalam membaca al-Qur'an di antaranya kognitif, afektif dan psikomotorik yaitu dengan mengajarkan tentang huruf-huruf hijaiyah, dan mempraktekkannya serta diharapkan mampu menghayati serta mengamalkannya dalam kehidupan sehari-hari.

Materi Pembelajaran Baca al-Qur'an di TPA Bani Lathif cukup sederhana dari segi materi dibandingkan dengan metode lainnya (iqra', barqi, jibril, tilawati dan lainnya), sehingga memudahkan santrisantri untuk mempelajarinya. Bahkan santri juga hafal dan lancar dalam membacanya, karena cukup banyak contoh-contoh yang diberikan. Selain itu dalam Pembelajaran Baca al-Qur'an di TPA Bani Lathif juga menjadikan santri tahu macam-macam bacaannya, seperti bacaan mad, bacaan nun sukun atau tanwin bertemu huruf-huruf hijaiyah dan lain-lain. Bagaimana cara membacanya, berapa panjang bacaannya. Karena guru menjelaskan bacaan tersebut dengan disertai pengertian atau definisi. Serta materi tambahan sebagai penunjang santri untuk melanjutkan ke jenjang selanjutnya.

Metode Pembelajaran Baca alQur'an di TPA Bani Lathif anak yang digunakan pun bervariasi (individual atau klasikal, klasikal baca simak (tadarus), metode bermain dan bercerita), sehingga dapat mengoptimalkan dalam pembelajaran dan memberikan warna dalam wawasan pendidikan al-Qur'an .

Berdasarkan pengamatan penulis dan hasil analisis sistem-sistem yang digunakan dalam Pembelajaran Baca alQur'an di TPA Bani Lathif, penulis menyimpulkan di antaranya :

Sistem Individu atau Privat. Mengajar secara privat atau satu persatu di mana santri menghadap guru atau ke depan kelas satu-persatu untuk membacakan materi yang tertulis di papan tulis. Guru membimbing dan santri yang lain mengawasi bacaan yang salah. Guru dan santri mengevaluasi bacaan santri untuk mengulangi atau melanjutkan ke materi selanjutnya.

Sistem Klasikal. Mengajar dengan cara memberikan pengajaran secara bersama. Guru menyampaikan materi pokok secara garis besar dan prinsipprinsip yang mendasar. Materi yang ada dalam buku panduan dituliskan di papan tulis dengan jhat yang bagus kemudian dijelaskan dengan contoh-contoh dan cara membacanya dengan fasih satu demi satu.

Sistem Klasikal Baca Simak (tadarus). Pembelajaran ini dengan cara membaca bersama-sama dilanjutkan secara satu persatu, sedangkan yang lain menyimak. Dalam klasikal baca simak biasanya terfokus mempraktekkan bacaan dengan tajwid secara langsung dari mushaf al-Qur'an, sehingga santri mengerti cara membaca yang benar dan fasih baik satu persatu maupun dibaca bersama-sama. 
Teknik Cerita dan Bermain. Sebagai metode tambahan, dalam pembelajarannya menggunakan metode cerita (kisah Nabi) agar santri mengetahui sejarah Nabi dan menjadikan suritauladan. Dalam pembelajarannya digunakan pula metode bermain, agar santri tidak bosan dengan cara pembelajaran yang monoton. Variasi metode tersebut digunakan terutama saat mengajarkan Hafalan Bacaan Shalat (fardhu dan jenazah); Hafalan Do'a-do'a harian; Hafalan Surat-surat Pendek; Aqidah dan Akhlak; Latihan Menulis huruf Arab / Khot; Tajwid dan Kreativitas (Qasidah) / Keterampilan.

Reward and Punishment. Reward dapat diartikan sebagai alat pendidikan preventif dan represif yang menyenangkan dan bisa menjadi pendorong atau motivator belajar bagi murid; dan sebagai hadiah terhadap perilaku yang baik dari anak dalam proses pendidikan. Punishment (hukuman) tidak berupa tindakan kekerasan, akan tetapi dengan pemberian tugas yang berupa pekerjaan rumah atau hafalan. Adapun tugas ini diberikan pada saat materi tambahan dengan cara menuliskan atau menyalin huruf dan angka Arab yang tertulis di papan tulis. Apabila waktu tidak mencukupi, santri disuruh melanjutkan tugas tersebut di rumah agar santri untuk belajar lebih dan berlatih di rumah.

$$
\text { Hadiah akan berdampak }
$$
menyenangkan, sedangkan hukuman adalah sesuatu yang berdampak tidak menyenangkan. Dampak dari keberhasilan yang dicapai dapat menjadi penguat (reinforcement) terhadap hasil belajar. Sedangkan suatu hukuman sebagai dampak dari kegagalan dapat menghilangkan (ectinction) tingkah laku yang tidak diinginkan. Dengan memperoleh hadiah tersebut individu akan merasakan suatu insentif yang dapat memberikan rangsangan dan motivasi baru dalam belajar. Sedangkan dengan hukuman menyebabkan individu tidak mengulangi kegagalan yang dibuatnya.

$$
\text { Penelitian juga bertujuan }
$$
menganalisis kelebihan dan kekurangan, baik dari segi materinya atau pembelajarannya di TPA Bani Lathif.

Setiap metode memiliki kelebihan dan kekurangan. Adapun kelebihannya: Metode Pembelajaran Baca al-Qur'an di TPA Bani Lathif lebih sederhana (materi pokok), sehingga santri cepat menyelesaikannya, santri dalam waktu satu tahun saja sudah dapat khatam alQur'an. Karakteristik metode Pembelajaran Baca al-Qur'an di TPA Bani Lathif adalah pembahasan materi yang bertahap dari yang mudah ke yang sulit. Pemberian penjelasan materi disertai dengan pengertian atau definisi dari bacaannya, sehingga santri tidak bisa membaca tetapi mengetahui nama bacaannya. Dari segi susunan penulisan materinya adanya saling keterkaitan antara pokok bahasan satu dengan yang lainnya. Penekanan pada penulisan materi dari papan tulis menambah kuat penguasaan santri terhadap materi. Kemudian adanya materi tambahan sebagai penunjang dan materi hafalan.

Kekurangannya

Metode

Pembelajaran Baca al-Qur'an di TPA Bani Lathif pemberian contoh masih kurang memadai, ini disebabkan sedikitnya pokok bahasan yang menjadikan santri terkesan hafal daripada mengerti. Kurang teraturnya proporsi pokok bahasan, yang menyebabkan adanya pemadatan materi. Kurangnya buku panduan bagi guru tentang bagaimana cara mengajarkan Metode Pembelajaran Baca al-Qur'an di TPA Bani Lathif, selama ini hanya diwariskan dari generasi ke generasi. Pembelajaran Baca al-Qur'an di TPA Bani Lathif merupakan membutuhkan waktu untuk menyesuaikan dengan karakteristik santri di TPA Bani Lathif, serta masih menerima revisi dan masukan.

Bervariasinya penggunaan teknik belajar (individual, klasikal, klasikal baca 
simak, cerita, hadiah dan hukuman). Kualifikasi guru yang berlatarbelakang pendidikan madrasah sebagai upaya meningkatkan pengetahuan guru tentang pembelajaran al-Qur'an. Penguasaan guru menunjang lebih optimal dalam pembelajaran dan mampu memaksimalkan media dan sarana prasarana yang ada. Adanya koordinasi guru meski tidak selalu formal menyebabkan hubungan antar guru dan pemecahan masalah yang dialami dalam pembelajaran lebih baik.

Namun, kurangnya tenaga bantu pengajar/ asisten dalam kelas, terkadang terjadi kesulitan dalam mengkondisikan kelas. Belum diberlakukannya pula RPP dalam pembelajaran, sehingga menjadi beban dan kurang seragam, sehingga kurang efisien dan efektifnya waktu serta penguasaan materi pada guru. Perbedaan tingkat kemampuan santri dalam penguasaan materi juga menyebabkan adanya kesenjangan dalam pemberian materi pokok (dalam pembelajaran klasikal). Keterbatasan media atau sarana prasarana, sehingga guru memanfaatkan media yang ada. Materi yang padat, dan waktu pembelajaran yang terbatas sekitar 120 menit, menyebabkan kurang optimal dalam memberikan materi pokok dan tambahan.

\section{KESIMPULAN DAN SARAN}

Berdasarkan penelitian dan pembahasan tentang Implementasi Metode Pembelajaran Baca al-Qur'an di Taman Pendidikan al-Qur'an (TPA) Bani Lathif Bandar Lampung, maka penulis dapat menyimpulkan sebagai berikut :

Hasil penelitian menunjukkan pembelajaran baca al-Qur'an di TPA Bani Lathif dapat dideskripsikan melalui pelaksanaan komponen-komponen pembelajarannya. Dari aspek tujuan, penguasaan huruf hijaiyyah, tanda baca, tajwid dan dapat mempraktikkan baca alQur'an dengan baik dan benar sesuai dengan kaidah makharijul huruf. Mereka diharpkan pula dapat menghayati dan mengaplikasikannya dalam kehidupan sehari-hari. Dari segi materi, lebih sederhana daripada metode lainnya, di mana santri tidak diberikan buku paket, namun materi dituliskan di papan tulis untuk melatih keterampilan menulis dan memperkuat hafalan, meski terkesan kurang efisien. Sistem yang digunakan dalam pembelajarannya antara lain dengan variasi sistem individual/ private, klasikal dan klasikal tulis, baca simak "tadarus". Adapun media yang digunakan masih sederhana yakni dengan mengoptimalkan yang ada, dan menuntut kreativitas guru. Evaluasi dilakukan melalui tiga tahapan: evaluasi harian, evaluasi pergantian pokok bahasan; evaluasi khatam al-Qur'an atau tes kelulusan. Meskipun demikian, dalam pelaksanaan belum terdapat perencanaan tertulis sebagaimana pada pendidikan formal, yang mengharuskan guru untuk membuat RPP sebelum melakukan proses pembelajaran.

\section{REFERENSI}

Asy'ari, M. K. (2014). Metode Pendidikan Islam. Qathruna, 1(1), 193-205.

Iqbal, M., \& Rizal, M. (n.d.). Kontribusi Dayah Darul Iman Dalam Perbatasan Buta Al-Qur'an di Blang Cot Tunong. Lentera: Jurnal Ilmiah Sains Dan Teknologi, 13(1), 1-16.

Irawan, M. D., \& Herviana, H. (2018). Implementasi Logika Fuzzy Dalam Menentukan Jurusan Bagi Siswa Baru Sekolah Menengah Kejuruan (SMK) Negeri 1 Air Putih. Jurnal Teknologi Informasi, 2(2), 129-137. https://doi.org/10.36294/jurti.v2i2 .427

Jafri, J. (2021). Upaya Guru Pendidikan Agama Islam dalam Meningkatkan Pemahaman Keagamaan Siswa. AlLiqo: Jurnal Pendidikan Islam, 6(1), 10-33.

Latifah, N., Sholihin, M., \& Nugroho, A. S. 
(2021). Tahsin Al-Qur'an dengan Metode Bani Lathif di Taman Pendidikan Al-Qur'an (TPA). Jurnal Ilmu Agama Islam, 3(1), 58-68.

Mesnawi, M., \& Najamuddin, M. (2015). Upaya Meningkatkan Kemampuan Membaca Al-Qur'an Dengan Menggunakan Metode Iqra' di SDN Jepara I-Surabaya. In Universitas Muhammadiyah Surabaya.

Munirah, \& Ladiku, N. S. (2019). Pengembangan Sikap Keberagaman Peserta Didik. Jurnal Ilmiah AlJauhari: Jurnal Studi Islam Dan Interdisipliner, 4(2), 336-348.

Nasution, M. H. (2020). Metode Nasehat Perspektif Pendidikan Islam. AlMuaddib: Jurnal Ilmu-Ilmu Sosial Dan Keislaman, 5(1), 53-64.

Puspita, R. M., Arini, A., \& Masrurah, S. U. (2016). Pengembangan Aplikasi Penjadwalan Kegiatan Pelatihan Teknologi Informasi Dan Komunikasi Dengan Algoritma Genetika (Studi Kasus: BPRTIK). Jurnal Online Informatika, 1(2), 7681. https://doi.org/10.15575/join.v1i2. 43

Ulfah, T. T., Assingkily, M. S., \& Kamala, I. (2019). Implementasi Metode Iqro' Dalam Pembelajaran Membaca AlQur'an. TA'DIBUNA: Jurnal Pendidikan Agama Islam, 2(2), 5969. https://doi.org/10.30659/jpai.2.2.4 4-54

Zaini, H. (2019). Bencana Menurut Perspektif Al-Qur'an. El-Hekam, 4(1), 1-10. https://doi.org/10.31958/jeh.v4i1. 1998 